Т. А. Ільїна

канд. пед. наук, доцент

\title{
РОМАН КРІСТОФА РАНСМАЙРА «ОСТАННІЙ СВІТ» ЯК ВЗІРЕЦЬ ЛІТЕРАТУРИ ПОСТМОДЕРНІЗМУ
}

У статті розглянуто особливості сюжету, художню своєрідність роману сучасного австрійського письменника Крістофа Рансмайра «Останній світ», який вважається одним із найкращих досягнень літератури постмодернізму.

Восени 1988 року спалахи літературної реклами німецькомовного світу були спрямовані на роман 34-річного австрійця Крістофа Рансмайра «Останній світ». Ця книжка стала сенсацією. Засоби масової інформації вміло підготували ії презентацію в центрі віденського авангарду «Сецесюн».

Твір Крістофа Рансмайра поряд із «Парфумером» Патріка Зюскінда та «Ім'ям троянди» Умберто Еко одностайно зарахували до найкращих досягнень літератури постмодернізму [6, 193]. Роман приніс К. Рансмайру широке визнання в Австрії та за межами його батьківщини.

Характерними рисами постмодерністської прози є забарвленість іронією, гра з «чужими» текстами, змішування різноманітних стилів. Провідною її ознакою є також пародіювання елементів масової літератури - детективних та історичних сюжетів.

Одним 3 найпопулярніших жанрів постмодерністської літератури $\epsilon$ роман - жанр, що відтворює життя у всій його широті й багатоманітності.

I оскільки постмодерністській свідомості властиве уявлення про неможливість пояснити буття за допомогою якоїсь однієї концепції, то породжена цією свідомістю картина світу в романі зазвичай набуває характеру своєрідної мозаїки різних істин, тобто різних рівноцінних трактувань реальності $[4,456]$.

Як зазначає Б. Бігун, «навколишній світ у постмодерністському романі осмислюється не як стабільна і впорядкована система з чіткими внутрішніми межами, а як художній текст 3 притаманною йому ілюзорністю, суб'єктивно-творчим способом упорядкування подій, принциповою відкритістю для різних оцінок і тлумачень, залежно від яких його значення може істотно змінюватися» $[1,74]$.

Історія «Останнього світу» досить незвичайна. Працюючи над прозовим переказом славетних «Метаморфоз» античного поета Овідія, інтерпретуючи їх, Рансмайр відчув, що виходить за межі просторово-часової структури «Метаморфоз», що вічні образи й теми античної міфології живуть у сучасності. «Ці образи супроводжували мене понад чотирнадцять років», зізнався письменник. Так з'являється оригінальний задум, своєрідна міфологізація дійсності. К. Рансмайр дає лаконічну характеристику змісту свого твору: «Тема - зникнення і реконструювання літератури, поезії; матеріал «Метаморфози« Публія Овідія Назона». У романі примхливо перетина- 
ються реальність давнього світу, міф і сучасність, герої Овідієвих «Метаморфоз» упізнаються в образах мешканців провінційного містечка.

Образи роману можна поділити на історичні й міфологічні. До перших належить поет Овідій, імператор Октавіан Август і молодий римлянин Котта. До других - постаті, що складають суспільність Томів, запозичені 3 Овідієвих «Метаморфоз». Рансмайр додає до свого твору своєрідний довідничок - «Овідіїв репертуар», де коротко характеризує персонажів «Останнього світу» та їхніх прототипів у давньому світі.

У формі енциклопедично стислого викладу автор створює невеликий подвійний ескіз до кожного персонажа роману, проводячи паралель між міфологічними й історичними постатями, цитуючи відповідні місця з Овідієвих «Метаморфоз» чи інших літературних та історичних джерел. Письменник дає інтерпретацію персонажів, пояснює їхнє місце в сюжеті та в образній системі, роль у розвитку авторської думки $[6,195]$.

«Ніщо не зберігає свою подобу» $[4,90]$ - ці слова стають лейтмотивом роману К. Рансмайра, твір якого став першим зверненням до «Метаморфоз» Овідія у формі роману. І хоча К. Рансмайр гостріше, ніж сам Овідій, підводить читача до усвідомлення плинності стану речей, уже те, що сучасний письменник знаходить спільну мову з поезією, віддаленою від нас тисячоліттями, заперечує це. У самій мінливості прихована сталість. Усе повертається, знову і знову повторюється.

Мистецтво, зображаючи різноманітні стани людської душі, фіксує їх у часі. Необхідні лише певні орнаментальні елементи, щоб пов'язати новий тип твору з попереднім досвідом читачів, нагадати, що розлука й страждання, дружба й кохання, натхнення й творчість - це почуття, добре знайомі світові.

Роман Крістофа Рансмайра - не тільки одна зі спроб оригінальної інтерпретації античності. Це твір про вічність і плинність, самотню долю й неприкаяність таланту не лише у вигнанні, а й у власній вітчизні, у суспільстві не схожих на нього, про всю гаму людських почуттів, що реагують на найменші дисонанси. Знайти спільну мову з читачем автору допомагають паралелі із загальновідомим - із символікою античної міфології.

«Метаморфози» Овідія, та й сама особистість великого поета, доля якого стала однією $з$ найдавніших ілюстрацій конфліктних взаємин митця та влади, настільки захопили Рансмайра, що він написав свій роман.

Дія в романі - постійний пошук. Так, автор вдається до реконструкції поезії, причому поле дії роману виходить за будь-які часово-просторові обмеження.

Основною ідеєю твору є заперечення лінійного розвитку. Духовне матеріалізується у формі кола, відповідаючи поняттю центричного часу: все повторюється, людство не розвивається, а просто існує [6]. Так у романі створюється специфічне позачасове тло, яке руйнує традиційні уявлення про історичний прогрес і поступальний рух історії від минулого до майбутнього. 
Події, змальовані в «Останньому світі», відбуваються і в античності, i в сьогоденні. Сплав минулого, сучасного й майбутнього в єдине ціле набуває в романі позачасових рис. Роман характеризується виразною антитоталітарною спрямованістю, яка виявляється передусім в одній 3 основних тем твору - протистоянні митця владі.

Критика тоталітаризму переплітається в романі 3 темою морального занепаду людства. Катастрофічними є метаморфози, які відбуваються 3 ожилими персонажами книги Овідія, яких автор зображує здеградованими. Тож у певному розумінні роман К. Рансмайра можна розглядати і як твірпересторогу [2, 458].

Тема культури, з якою пов'язаний образ зниклої крижки, - це ще один тематичний напрямок роману. Підкреслюючи його значущість, літературознавець О. Карельський охарактеризував «Останній світ» як роман про смисл мистецтва загалом, про найглибинніші питання взаємовідношень поетичної творчості й людського буття, про долю європейської цивілізації $[5,5]$.

Давньоримський поет стає центральною постаттю твору. Дія, у якій беруть участь усі персонажі, постійно розігрується навколо особистості Овідія, хоча протягом усього роману він не з'являється жодного разу. Античний поет - безпосередній натхненник «Останнього світу». «Метаморфози» Овідія створюють образну систему і самі стають суб'єктом сюжету - це явище часто зустрічається в літературі XX ст.

Твір насичений майстерно переданими переходами від реальності до сну, сповненими таємниць травестійними та гротескними сценами. Страхітливі видіння античності стають реальними снами сьогодення.

Роману К. Рансмайра притаманна надзвичайна мальовничість зображення, у ньому виявляється характерна для літератури XX ст. активна взаємодія різних видів мистецтва: літератури, живопису, кіно. Гинуть цивілізації, змінюється світ, але творчий геній життя непоборний та вічний - такий пафос цього роману, написаного чудовою виразною мовою.

Крістоф Рансмайр багатьма вважається головним німецькомовним автором сучасності. Дебютував на початку $80-\mathrm{x}$ pp. XX ст. і за більш ніж двадцять років написав лише три романи - популярно-пригодницький «Жахіття криги і пітьми» (1984), магічно-реалістичний «Останній світ» (1988), альтернативно-історичний «Хвороба Кітахари» (1995), але кожний 3 них став літературною подією світового масштабу.

Крістоф Рансмайр, безумовно, зірка на літературному небосхилі. Варіативність історії, романтика, містика - все це в моді, тому не дивно, що Рансмайр такий популярний у молодіжному читацькому середовищі. Всім його романам критики найпрестижніших видань дали найвищі оцінки, вони дуже швидко знайшли широке коло читачів у всьому світові, здобувши спочатку визнання в німецькомовних країнах, а протягом достатньо короткого часу були перекладені 26 мовами світу. 


\section{Список використаної літератури}

1. Бігун Б. Я. Митець і його творіння за постмодерністської доби // Всесвітня література в середніх навчальних закладах України. - 2002. - № 5-6. - С. 74-81.

2. Волощук Є. В. Зарубіжна література: Підручник для 11-го класу загальноосвітніх навчальних закладів. - К.: Генеза, 2004. - 464 с.

3. Рансмайр К. Останній світ: Роман / Пер. 3 нім. О. Логвиненко // Всесвіт. 1992. - № 3-4. - С. 3-102.

4. Рансмайр К. Останній світ: Роман: Наша міні-хрестоматія // Всесвітня література в середніх навчальних закладах України. - 2002. - № 5-6. - С. 87-102.

5. Рансмайр К. Последний мир: Роман с Овидиевым репертуаром / Пер. с нем. Н. Федоровой; предисл. А. Карельского. - М.: Радуга, 1993. - 208 с.

6. Цибенко Л. Б. Крістоф Рансмайр і його роман «Останній світ» // К. Рансмайр. Останній світ. - К.: Основи, 1994. - 208 с. - С. 193-206.

\section{Summary}

In clause features of a plot, an art originality the novel of modern Austrian writer Kristofa Ransmajra «Last world» which is considered one of the best achievements of the literature of a postmodernism are considered. 